\title{
Creating French-style pension funds: business, labour and the battle over patient capital
}

\author{
Marek Naczyk, Department of Social Policy and Intervention \\ marek.naczyk@spi.ox.ac.uk
}

This is the pre-submission version of a paper published in the Journal of European Social Policy (2016)

\begin{abstract}
Over the past few decades, European governments have increasingly retreated from public pension provision and promoted the expansion of private retirement savings accounts. Analysts of comparative social policy have traditionally considered that the politics of pension privatisation has been driven by politicians' and socio-economic actors' concerns about the relative generosity and costs of different pension arrangements. But, when they are fully-funded instead of being financed on a pay-asyou-go basis, pension arrangements generate funds that are injected into the financial system. The existence of such a welfare-finance nexus means that stakeholders in the pension system are also attentive to how pension funds invest their assets, and may try to actively shape the institutional design of old-age pensions in accordance with such concerns. This paper focuses on the role of socio-economic actors - employers, trade unions and the financial services industry - in pension privatisation and develops theoretical expectations on how these actors' interest in maximising control over private pension plans' financial assets affects pension politics. The argument is tested with a case study of French pension debates between the 1980s and the 2000s.
\end{abstract}

\section{Keywords}

Pension privatisation, political economy, finance, corporate governance, France, interest groups, pension reform 


\section{Introduction}

Since the 1980s, European governments have retreated from public pension provision and promoted the expansion of private defined-contribution retirement accounts (Ebbinghaus, 2011; Immergut et al., 2007; Orenstein, 2013). This trend towards pension privatisation and individualisation has significant distributional consequences. Because defined-contribution plans offer beneficiaries only the contributions they have paid into the system, plus returns, it is increasingly up to individuals - rather than to the state or employers - to decide how much they should save for their pension and to bear the risks involved with financial market fluctuations (Burtless, 2003; Hacker, 2004, 2006). Since participation in private pension plans is generally incentivised through tax deductions, it tends to benefit high-income earners (Hacker, 2002: 49). In addition, when private occupational plans are offered by an employer or through collective bargaining, coverage of such schemes may be very unequal (Meyer et al., 2007; Seeleib-Kaiser et al., 2012).

Due to these distributional implications, many political scientists have seen risk and income distribution as the central issue dimension of the politics of pension privatisation. In particular, comparative political economy scholars have developed theoretical expectations about workers' and employers' preferences regarding pension reform based on these actors' labour market needs (Häusermann, 2006, 2010; Mares, 2003; Oude Nijhuis, 2013; Swenson, 2002). The primary function of pensions has indeed been to insure workers against the risk of income loss in old age. Very frequently, corporate managers have also used occupational pension schemes to retain staff with valued skills. Decisions about workers' and employers' mutual rights and obligations, and about the costs of retirement benefits, are thus undoubtedly at the centre of most pension reforms.

Yet old-age pensions are not only characterised by their link with employment relations. As highlighted by the fiscal-centred perspective on welfare state development (Béland, 2014; Koreh, 2014; see also Martin et al., 2009), pension arrangements can be used for a variety of fiscal or macroeconomic purposes that are not directly linked to these arrangements' social aims. In particular, when - instead of being funded through direct transfers from the working-age population to pensioners ('pay-as-you-go' 
systems) - pensions are financed through an accumulation of assets over time ('fullyfunded' systems), they generate funds that are injected into the financial system and thus institutionalise a 'welfare-finance nexus' (Estévez-Abe, 2001). Economic geographers have shown how private pension funds' growing presence in financial markets has contributed to the emergence of a form of 'pension fund capitalism', particularly in Anglo-Saxon countries (Clark, 2000, 2003; Dixon, 2008). In this context, it has been claimed that pension privatisation can lead to a 'financialisation' of the economy (Dixon, 2014; Dixon and Sorsa, 2009; Engelen, 2003; van der Zwan, 2014): not only can saving for retirement turn individuals into everyday investors (Langley, 2008), but pension funds’ important equity holdings have also allowed them to press for a greater integration of 'shareholder value' in firms' governance and management practices (Gourevitch and Shinn, 2005; Lazonick and O’Sullivan, 2000).

However, not all private pension plans adopt shareholder value maximisation as their main objective. While pension funds usually try to diversify their portfolios in order to balance risks and rewards (Davis, 1995), many occupational schemes have preferred to reinvest their assets into their sponsoring companies, thereby providing these firms with cheaper and more 'patient' capital that has allowed them to grow in size (Estévez-Abe, 2001; Jackson and Vitols, 2001; Manow, 2001; Park, 2004). An increasing number of pension funds have also declared their readiness to promote 'socially responsible investment' that takes into account not only financial returns, but also non-financial - e.g. social, environmental or ethical - criteria in the investment process (Renneboog et al., 2008; Sparkes, 2002). Several political science studies have started mapping this variation in the regulations governing pension fund management and have highlighted the functional benefits derived by economic agents - primarily financiers and managers of non-financial firms - from different institutional arrangements (cf. Estévez-Abe, 2001; Jackson and Vitols, 2001; Manow, 2001). But these studies have analysed socio-economic actors' financial interests only after private pension plans have entrenched themselves, and have failed to examine how these actors' stances on the welfare-finance nexus lead them to actively influence the institutional design of such plans.

This paper argues that conflicts between financiers, managers of non-financial firms and trade unions for the control of private pension plans' financial assets are a 
crucial determinant of the institutional outcomes of pension privatisation. Not only do they directly influence the way pension funds are managed, but - as would be contended by the fiscal centred perspective on welfare state development (Béland, 2014; Koreh, 2014) - such 'non-social' motives may also have an indirect impact on the 'social' or distributional dimension of pension privatisation, in particular coverage of private retirement benefits. In highlighting these struggles and their implications, the paper challenges conventional wisdom according to which private pensions are characterised by a 'subterranean' form of policy-making and are 'likely to become a source of political conflict - if they become a source of political conflict - only after their creation, when their costs and benefits are both larger and potentially more apparent' (Hacker, 2002: 48, 24-25, 44). Although debates about the management of pension fund assets are often highly technical and unlikely to hit the headlines (see also Culpepper, 2011), different socio-economic actors have concentrated interests in the regulations governing retirement savings accounts and therefore press governments on this issue from the very start.

The next section presents the theoretical framework. The argument is then assessed with a case study of French pension reform between the 1980s and the early 2000s. The final section concludes and makes suggestions for future research on the influence of the welfare-finance nexus on pension politics.

\section{The welfare-finance nexus and control over pension arrangements}

While the comparative political economy (CPE) literature has considered the distribution of risk and income as forming the core of the politics of social policy - and in particular of pension - reform, Mares (2003) has argued that another politically contentious dimension has been the distribution of authority (or control) among employers, trade unions and the state over the management of social arrangements. Since social policies have many implications for the functioning of the labour market and considerable resources are allocated towards their financing, Mares has assumed that employers' and trade unions' primary motivation for trying to grant themselves decision-making powers in the administration of social programmes has been to exert further influence over issues - e.g. the determination of the level of insurance 
contributions and benefits - related to their labour market interests. Yet, when one takes into account the fact that social - and especially pension - arrangements can generate large sources of financial capital, it becomes clear that the capacity to influence the use of these assets may be another reason why a range of actors want to achieve control of the institutions managing social programmes.

Traditional CPE analyses focus on the role of employers and trade unions in social policy debates. But, once one views social arrangements from the angle of the 'welfare-finance nexus’ (cf. Estévez-Abe, 2001), the financial services industry appears to be another important socio-economic actor with its own distinct preferences. Financial - particularly insurance - companies are active in the social policy area because they are a potential provider of private social arrangements, including retirement savings products (Leimgruber, 2008, 2012; Meyer and Bridgen, 2012; Naczyk, 2013). In that role, financiers can be expected to have a strong interest in maximising control over pension plans. Although financial firms often act on behalf of workers and employers when these actors set up occupational pension schemes, direct control of pension plans can help financiers, firstly, to shape the fee structure so as to reap greater profits from the pension business and, secondly, to diversify the plans' investment portfolios in order to balance risk and returns.

In the same way as for financiers, the way pension fund assets are managed is not neutral for employers - i.e. here synonymous with managers of non-financial firms - and trade unions. Indeed, the financial flows generated by the development of retirement savings plans create both threats and opportunities for these socio-economic actors (Culpepper, 2011; Gourevitch and Shinn, 2005; Roe, 2003). This is especially the case if pension funds invest their assets in equities: Any investments they make in shares mean that they acquire an ownership stake in a company and can therefore directly influence its governance. In their role as investors in and owners of equity capital, pension funds - especially if they are controlled by a third party such as a financial firm - may have very different views from those of investee companies’ managers or workers. First, pension funds may have specific expectations as regards the goals a company should pursue: while managers and workers may strive to preserve their autonomy within the firm, pension funds may emphasise the idea that the investee firm should maximise its profits and shareholder value. If pension fund managers are 
not satisfied with the performance of a company, they can call for changes in its strategy, including restructurings that may result in significant job cuts, and, in order to achieve such changes, they can threaten to unseat incumbent company management (Useem, 1996). A second contentious issue has to do with how to act in case of a hostile takeover bid: although such bids bring a company's traditional strategic orientation into question and put the jobs both of its incumbent managers and its workers at risk, a pension fund controlled by a third party may be tempted to side with the highest - and thus potentially hostile - bidder.

Given the influence pension funds can have on the goals pursued by investee companies and on these firms' capacity to protect themselves when facing a hostile takeover bid, managers and trade unions have an interest in maximising their control over the way pension funds invest their assets. Both types of actors have a strategic aim in turning pension funds' investments into a form of 'patient capital' that helps investee firms develop their activities in the long term and potentially offers a protection against hostile takeovers. But their preferences may diverge on the specific tools that should be used to achieve this aim.

Managers of non-financial firms can be expected to have a preference for a direct reinvestment of pension fund assets into their own companies. A number of scholars have shown how pension schemes based on 'book reserves' - i.e. schemes that as such do not involve the creation of assets, but are financed through provisions set up on the liability side of companies' balance sheets - help managers to retain corporate earnings within their firms and thus provide them with an additional source of capital (Estévez-Abe, 2001; Jackson and Vitols, 2001; Manow, 2001). But an alternative means through which managers can shape pension plans in their own interest is to make them invest their assets in the equity capital of their sponsoring companies. Such self-investment ensures that pension funds vote in favour of their sponsoring firm's managers during shareholder meetings and that they remain loyal in case of a hostile takeover attempt.

Managers' focus on the reinvestment of retirement assets into their own companies may nonetheless be detrimental to the interests of workers. If a pension fund invests too large a part of its assets into its sponsoring company and if that company goes bust, workers may end up not only losing their jobs, but also their retirement 
savings. Hence, from a financial point of view, it is in workers' interest to have more diversified portfolios. However, given the potential impact of pension funds' investment decisions on workers’ position - e.g. wage levels, job security or access to training - in their companies, trade unions can be expected to seek to secure a more influential position in the governance of pension funds so as to ensure that, as shareholders, pension funds do not focus only on shareholder value creation, but also take into account the interests of the workers employed in their investee companies (see also Fung et al., 2001; Ghilarducci, 1992; Ghilarducci et al., 1997; Pontusson 1992).

In sum, due to the significance of pension funds' investments in the economy, socio-economic actors - financiers, managers of non-financial firms and trade unions may seek to control how pension funds invest their assets and, in particular, how they use their ownership stakes in publicly listed companies. Whereas financiers can be expected to emphasise the need to maximise returns and shareholder value in the short term, managers and organised labour may on the contrary seek to turn pension funds into a source of patient capital for investee companies. However, while managers sponsoring an occupational pension plan may want the plan to directly reinvest its assets into the sponsoring company, trade unions will - similarly to financiers - put greater emphasis on portfolio diversification so as to make workers’ pension savings safer. Because of their divergent interests, socio-economic actors will strive to maximise their own capacity to control pension funds. But their preferences also partly overlap and this creates room for compromises between them.

Debates over the control of pension fund assets are part and parcel of the politics of pension privatisation. If disagreements on this issue are strong, this may help block the adoption of government regulations over retirement savings plans. Yet the dimension of 'control' is defined not only by socio-economic actors' financial interests, but also - as has been pointed out by Mares (2003) - by their labour market interests. In that sense, it is not a fully independent issue dimension. Paradoxically, that lack of independence makes its influence potentially even larger. Thus, discussions over the management of pension fund assets may have a ripple effect on the dimension of risk and income distribution, and in particular on regulations regarding the coverage of pension plans. Depending on the type of control they will want to exert over a pension plan, socio-economic actors will prefer different types of coverage. Financiers can be 
expected to favour individual retirement savings plans where individuals directly enter into a contract with financial firm. The level of coverage will then depend on individuals' decisions. By contrast, with their emphasis on self-investment into the sponsoring companies, managers will favour occupational schemes set up at the level of the firm. Finally, trade unions' emphasis on portfolio diversification - but also a greater emphasis on redistribution among different groups of workers - should lead them to prefer more encompassing schemes set up either at the national level or at the industry level.

\section{The politics of pension privatisation in France}

This section assesses the relevance of the paper's theoretical framework by tracing socio-economic actors' involvement in political debates over the introduction of private pension funds in France since the 1980s. As has already been mentioned, the existing literature has assumed that private pensions are unlikely to become a bone of contention until they become truly institutionalised within a pension system (cf. Hacker, 2002). When measured in relation to gross domestic product, French - together with Greek and Luxemburg - pension fund assets have traditionally ranked lowest in Europe (OECD, 2009). Indeed, after the Second World War, the French pension system was dominated by the pay-as-you-go method of financing and crowded out the development of private pension funds (Ebbinghaus, 2011; Naczyk and Palier, 2011; Palier, 2007). Given these characteristics, France is a case where issues related to the control of pension fund assets should be least likely to influence socio-economic actors' preferences regarding pension reform.

Previous work by Palier (2007: 97-100) has already highlighted that considerations about pension funds' role in the economy and in corporate governance have helped structure debates about pension privatisation in France. Thus, Palier has shown how French organised interests and party politicians have presented the development of pension funds as a way to protect domestic companies against excessive foreign influence and, in the case of trade unions, as a way of strengthening workers' influence over the firm. But Palier argues that these socio-economic and political actors reached only an 'ambiguous agreement' among themselves, as they 
agreed solely on the principle of developing private pensions, but continued disagreeing on the technical content of reform (Palier 2007: 97). This section will show that agreeing on the precise content of the regulations governing the control and use of pension fund assets was in fact a necessary condition for pension privatisation in France. The first subsection maps socio-economic actors' preferences regarding pension fund regulation. The second subsection then shows how in the late 1990s leftwing politicians brokered a compromise between these actors over the content of reform.

Divergent preferences over the regulation of pension funds

At the end of the 1970s, a number of actors linked with the financial services industry put the introduction of private retirement savings plans on France's political agenda. Thus, in 1979, the UAP (Union des Assurances de Paris) - France's largest state-owned insurance company - launched an advertising campaign with the following slogan: 'Babies born in 1949, don’t count too much on babies born in 1979 to pay for your pensions' (own translation). In 1982, two economists - Dominique Strauss-Kahn and Denis Kessler - published a high-profile study, which called for the development of private pension plans and received considerable media attention after it was published as a book (Kessler and Strauss-Kahn, 1982). The study had been commissioned by the International Association for the Study of Insurance Economics (more commonly known as 'the Geneva Association') - a think tank founded and funded by major European insurance companies (Leimgruber, 2012). At the political level, insurers found an important ally in Raymond Barre - France’s right-wing Prime Minister between 1978 and 1981, but also first chairman of the Geneva Association between 1973 and 1976. Barre made regular declarations in favour of the introduction of private pension funds (e.g. L'Express, 1978; Barre, 1984). When his party - the UDF (Union pour la Démocratie Française) - formed a coalition government with Jacques Chirac's Gaullist RPR (Rassemblement pour la République) party in 1986-1988, the Chirac government created specific tax deductions for individual retirement savings plans called PERs (plans d'épargne pour la retraite). 
The PERs were nonetheless repealed in 1989 by a left-wing government. Trade unions, but also employers involved in the management of occupational pay-as-you-go pension schemes, protested against their expansion for fear it would threaten the existence of the pay-as-you-go system (Naczyk, 2013: 457-459). But managers of large non-financial companies and trade unions also had concerns about how pension funds would manage their assets and whether their time horizon would make them providers of 'patient capital'. As the debate about the introduction of private pension funds continued in the early 1990s, various business associations put forward proposals concerning their preferred institutional design of funded pensions.

In 1991, the Institut de l'Entreprise - a corporate think tank funded by large firms - published a report about needed changes in the shareholding structure of French companies (Institut de l'Entreprise, 1991). Although large publicly listed companies had built networks of mutual shareholdings in the 1980s in order to protect themselves against hostile takeovers (see Culpepper, 2011), French senior managers worried that this might not suffice. In that context, the report's authors - including Arnaud Leenhardt, president of the powerful Union of Metal and Mining Industries (UIMM Union des Industries Métallurgiques et Minières) - called for the development of pension funds, but insisted that these should be loyal shareholders who would provide managers with the stability they needed to implement their companies' strategies. In their words: 'the company is a project' and 'the realisation of that project is necessarily a long-term undertaking' (Institut de l'Entreprise, 1991: 15-16; emphasised in the original document). Whereas the PERs had been individual plans directly controlled by financial services companies, the report cited existing occupational 'company savings plans' (plans d'épargne d'entreprise - PEE) as a potential vehicle for retirement savings. PEEs traditionally allowed workers to build up tax-free savings that were matched by employer contributions. Managers of large companies typically set them up in order to encourage employee loyalty, but also in order to provide a potential defence against hostile takeovers. Indeed, PEE assets could be fully self-invested in the sponsoring company's equity capital.

While the Institut de l'Entreprise advocated the expansion of fully-funded pension plans, some industrialists - in particular, Jean-Louis Beffa, the long-time chairman and chief executive officer of building materials manufacturer Saint-Gobain - 
entertained the idea of developing occupational book-reserve schemes ${ }^{1}$. This financing technique consists in reporting pension liabilities on a firm's balance sheet. Because book-reserve schemes provided large German firms with internal finance for capital investments (Jackson and Vitols, 2001), they were considered by French industrialists as one of the pillars of post-war German industrial power. This type of institutional design for supplementary pensions was publicly backed in October 1992 by the AFEP (Association Française des Entreprises Privées), a lobby that represents France's largest publicly listed companies (see Charpentier, 1997).

A socialist government started exploring the possibility of expanding PEEs or introducing book reserve schemes. In 1991, Minister of Industry Dominique StraussKahn commissioned a report whose official aim was to examine what role PEEs might play in the financing of the economy, but whose informal goal was to gauge whether they could serve as a vehicle for retirement savings plans. Reformist trade unions such as white-collar employees' CGC, the Christian-democratic CFTC and the socialdemocratic CFDT signalled that they might back the expansion of PEEs, provided these would not be called 'pension funds' and on the condition that, instead of being established unilaterally by employers as was traditionally the case with PEEs, they would have to be set up via collective agreements, thereby providing organised labour with greater control over the plans' design and management (e.g. Le Monde, 1992). Trade unions also opposed the possibility for PEEs to reinvest too large a part of their assets into their sponsoring company because this could threaten the safety of workers' savings. In this context, the authors of the report commissioned by Strauss-Kahn recommended the creation of 'employee savings plans' (PES - Plan d'épargne salariale), which would meet unions' demands, with the exception of self-investment, since as much as $50 \%$ of the assets could be self-invested in the sponsoring company (see Pastré and Moscovici, 1992).

Given managers' and trade unions' emphasis on greater control over the design and management of retirement savings plans, the French Federation of Insurance Companies (FFSA - Fédération Française des Sociétés d'Assurance) - led from 1991 by economist Denis Kessler - suggested the creation of 'French-style pension funds'

\footnotetext{
${ }^{1}$ Interview senior manager in insurance industry, Paris, September 2009. Interview, senior manager in manufacturing industry, Paris, $5^{\text {th }}$ October 2011.
} 
(fonds de pension à la française). Such funds would be established mainly through firm- or industry-level collective agreements and, while they would be effectively managed by financial firms, their administration would be supervised by employers and trade unions (FFSA, 1991). Insurers were opposed to self-investment as proposed by managers, but senior figures in the industry insisted that insurance companies were loyal shareholders who would protect investee companies against hostile takeovers. For example, in his book Capitalism Against Capitalism, Michel Albert - president of insurance company AGF - wrote that pension funds should be introduced in France 'on the condition that [they] are managed with the "creative caution" typical of the Alpine model (whose institutional investors provide stability, unlike those in America and elsewhere who have succumbed to the lure of short-term speculation)' (Albert, 1993: 98). Similarly, the president of the UAP, Jean Peyrelevade, wrote about his own company that it was there 'to make sure that long-term concerns prevail' and that '[the UAP's] expectation of profits, always expressed in a long-term perspective, comes second after [its] concern for preserving the independence and stability of the structures in which [it] invests the assets that [it] manages’ (Peyrelevade, 1993: 66-67).

Despite insurers' attempts to woo managers of large non-financial companies, both types of actors - as well as trade unions - continued having divergent views on the content of the regulations governing the use of pension fund assets. Thus, when the CNPF (Conseil National du Patronat Français) - France's largest employers' association - took the initiative in 1993 to develop a common stance on retirement savings plans, divisions within the business community forced the interest group to include the various - and contradictory - proposals defended by financiers and industrialists in its final report (Charpentier, 1997: 305-328). Different segments of business and trade unions continued lobbying politicians in different directions ${ }^{2}$.

\section{Building compromise}

Left- and right-wing governments remained for a long time reluctant to submit a bill on private retirement savings due to the contentiousness of the issue. In 1997, Jean-

\footnotetext{
${ }^{2}$ Interview senior manager in insurance industry, Paris, September 2009. Interview, senior manager in manufacturing industry, Paris, $5^{\text {th }}$ October 2011.
} 
Pierre Thomas, a parliamentarian from the right-wing UDF party, managed to garner enough support for his own bill on defined-contribution 'retirement savings plans' (plans d'épargne retraite - see Conceição-Heldt, 2006: 184-187). Such schemes would be primarily set up by employers for their own employees and would have to be managed by external asset managers, although they would be supervised by boards composed of employers and employees. The Thomas Law was welcomed both by the financial services industry and by the CNPF (Bollon and Cossic, 1997). But it attracted criticism from trade unions and from senior industrialists. Organised labour continued fearing that the development of private pension funds could 'drain the resources' of France's dominantly pay-as-you-go pension system (Les Echos, 1996b). Trade unions also opposed the bill because it gave too minor a role to collective bargaining, and thus gave them too little influence in defining the funds’ design.

By contrast, senior industrialists criticised the bill because it would not provide the patient capital they were calling for. Indeed, the bill limited the possibility for selfinvestment: A maximum of 5\% of assets could be held in securities issued by a single company. The head of Saint-Gobain, Jean-Louis Beffa, declared that: 'Pension funds are important only because they establish a French institutional presence in companies’ capital. But there is no way [they] will provide support for strategies different from those of Anglo-Saxon pension funds' (Les Echos, 1996a). The issue of patient capital became all the more salient for managers of large firms - and increasingly for trade unions - because the parliamentary debate over the Thomas Law happened to coincide with a major development in France's system of corporate governance. In November 1996, insurance company UAP was taken over by AXA. These two companies occupied an important position in a system of mutual shareholdings that had protected France’s largest firms against hostile takeovers since the 1980s. Consequently, their merger was widely seen as triggering the unwinding of these cross-shareholdings and as giving greater weight to foreign shareholders in French companies' capital (Culpepper, 2011).

During the 1997 legislative campaign, socialist politicians - and their leader Lionel Jospin - promised they would repeal the Thomas Law, were their party to win the election. But it soon became apparent that some left-wing politicians were intent on introducing retirement savings plans and that they would try to broker a compromise 
between organised interests on this issue. A month after becoming Minister of Finance in the Jospin government, Dominique Strauss-Kahn announced he would launch a series of consultations on the introduction of funded pensions (La Tribune, 1997). As it was becoming clear that the AXA-UAP merger had made French companies much more vulnerable to hostile takeovers, both Strauss-Kahn and right-wing President Chirac talked about the need to introduce 'French-style pension funds' in order to create stable domestic shareholders in France's 'capitalism without capital' (Le Monde, 1997a; Le Monde, 1997b). Strauss-Kahn also underlined that pension funds should be 'more collective, include more solidarity' and allow for greater involvement of trade unions in their establishment and their management (La Croix, 1998).

In the context of the unwinding of large firms' mutual shareholdings, trade unions started putting a greater emphasis on how the development of alternative pension funds through 'employee savings schemes' (épargne salariale) would help create loyal domestic shareholders for French companies. This even became organised labour's main line of argument in justifying the expansion of such schemes (Palier, 2007: 98-99). Unlike Anglo-Saxon pension funds, French employee savings plans would not have 'exorbitant demands' on shareholder value and would support their investee companies’ long-term strategies (Libération, 1999). The social-democratic CFDT union evinced interest in promoting 'solidaire' investment that would 'support job-creating companies' (Le Monde, 1998b). Given the significance of the changes that were taking place in France's system of corporate governance, even the communist CGT union indicated its readiness to take part in the debate (La Tribune, 1998; see also Le Duigou and Toulisse, 1999).

Unions' increasing emphasis on the role employee savings schemes could play in providing patient capital created room for a compromise with industrialists. A forum for discussion was provided by the Fondation Saint-Simon - a think tank gathering intellectuals, businessmen, but also leading figures of the CFDT. In a note written for the foundation, Saint-Gobain's Jean-Louis Beffa and his co-authors contended that workers’ greater involvement in companies’ equity capital - for example through pension funds - could 'protect the employment relationship from the vagaries of finance' (Beffa et al., 1999: 3). Beffa now put less emphasis on self-investment into the sponsoring companies and proposed to 'develop original wage-earner funds whose 
objectives could incorporate other criteria than financial performance in a narrow sense' (Beffa et al., 1999: 34). In fact, representatives of the financial services industry also showed openness towards such forms of 'socially responsible investment', which could be introduced while maintaining diversified portfolios. The French association of asset managers (AFG - Association française de la gestion financière) signalled that 'people in the trade would be able to respond to market demand' (Le Monde, 1998a; see also Peyrelevade, 1998).

Socio-economic actors' diverging preferences on the technical regulations governing the control and use of pension fund assets and the compromise they gradually reached over these issues had a significant influence on the institutional design of retirement savings plans prior to their introduction in France. In early 2000, the Jospin government and a new Minister of Finance, Laurent Fabius, presented a bill on 'employee savings plans', which was eventually enacted in February 2001. The Fabius Law created 'voluntary partnership employee savings plans' (PPESV - plans partenariaux d'épargne salariale volontaires) as well as 'multi-company savings plans' (PEI - plans d'épargne inter-entreprise). Like the existing PEE company savings plans, these new schemes would be defined-contribution and would be based on workers' voluntary contributions potentially supplemented by employer matching contributions. All these schemes would have to be created through collective agreements signed by employers and trade unions. Workers and employers would have equal representation on the plans' boards.

The creation of multi-company PEI plans was largely the result of unions' demands and an example of how socio-economic actors' agendas related to the welfarefinance nexus can indirectly affect the distributional dimension of pension reform. Organised labour wanted to use such schemes to extend coverage of employee savings to workers employed in small- and medium-sized firms (e.g. Le Duigou and Toulisse, 1999). But greater coverage and a greater number of participants would also ensure that more savings would be put into the schemes, thereby increasing their firepower when acting as shareholders of publicly listed companies. Emblematic of the role salary savings schemes were to play in providing patient capital to French companies was the Fabius Law's requirement that the funds managing épargne salariale report annually about their taking into account social, ethical and environmental criteria. In order to 
play an active role in the schemes' management, several unions launched an 'interunion committee on salary savings' (Comité intersyndical de l'épargne salariale), which has provided them with expertise in pressing for socially responsible investment and in making recommendations on the funds' voting policies (Théry, 2002). A former general secretary of the CFDT union also created Vigeo - a non-financial rating agency whose shareholders have been a number of European trade unions, but also asset managers and major French companies (Notat, 2003: 24-26).

The state gave another boost to the strategy of promoting 'French-style pension funds' as providers of patient capital for domestic companies. Thus, in 2002, the Jospin government decided that the Fonds de réserve des retraites (FRR) - a newly created buffer fund of the main public pay-as-you-go pension scheme - would have the majority of its assets managed by private asset management firms - typically the same that would manage salary savings schemes - that would pursue a socially responsible investment strategy. The government nominated Jean-Louis Beffa and the communist CGT union's pensions expert, Jean-Christophe Le Duigou, as vice-chairmen of the FRR (see Beffa et al., 2005). In 2003, a new right-wing administration - and the Fillon pension reform - changed the name of the PPESV 'voluntary partnership employee savings plans' into 'collective retirement savings plans' (PERCO - Plans d'épargne pour la retraite collectifs), but did not dramatically change their institutional design. Simultaneously the Fillon reform created a mandatory pension fund for civil servants called ERAFP (Etablissement de retraite additionnelle de la fonction publique; see Dixon, 2008), which, in the same way as salary savings schemes and the FRR, would pursue a strategy of socially responsible investment in cooperation with private-sector asset managers.

\section{Conclusion}

This article has argued that socio-economic actors' efforts to shape the institutional design of old-age pensions are not only driven by their labour market interests, but also by concerns about how pension funds should invest their assets. Depending on who controls the management of pension arrangements, the assets generated by such institutions may be channelled differently into the financial system, and thus empower 
different actors within the economy. Using the example of France - a country whose pension system has traditionally been overwhelmingly financed on a pay-as-you-go basis -, the paper has shown how, once pension privatisation appears on the political agenda, socio-economic actors try to obtain regulations that maximise their control over the management and use of pension fund assets. Thus, in France, after financiers started pushing for the creation of individual retirement savings accounts in the 1980s, industrialists and trade unions called for alternative - occupational - arrangements that would provide patient capital to French companies and potentially offer a protection against hostile takeovers. However, since organised labour did not agree with industrialists' intention to have retirement savings plans self-invest their assets in their sponsoring companies, politicians brokered a compromise between trade unions, industrialists and financiers over the development of retirement savings plans that would have diversified portfolios, but would invest their assets in a 'socially responsible' way and thus still provide patient capital to domestic companies. Finding a compromise over these issues was a necessary condition for reform. As long as socioeconomic actors did not agree on the content of regulations concerning the control and potential use of pension fund assets, pension privatisation did not have wide political support and governments were reluctant to introduce legislation that would promote the expansion of private retirement savings plans in France.

Are these findings only confined to the French case? There is no doubt that a systematic investigation is needed to verify the wider applicability of the hypotheses developed in the paper. But existing case studies of pension reform have already started providing cross-national evidence that socio-economic actors' agendas for pension reform have been strongly influenced by their concerns about the shape of the welfarefinance nexus. The evidence is clearest in the case of trade unions. Indeed, organised labour has tried to wield greater power over the management of pension fund assets both in countries with well-developed pension funds - such as Sweden (Pontusson, 1992), the United States and Canada (Fung et al., 2001; Jacoby, 2008) - and in those with emerging pension fund industries - e.g. Brazil (Chaves Jardim, 2013). Unions have typically sought to turn pension funds into socially responsible investors that take into account the impact of corporate decisions on workers' position in the company. In 
1999, trade union officials even created a global Committee on Workers' Capital in order to promote transnational cooperation on this issue (Habbard, 2011: 68).

The literature on the politics of corporate governance reform has also shed light on how managers of large companies have typically resisted pressures for shareholder value maximisation exerted by institutional investors such as pension funds (Culpepper, 2011; Gourevitch and Shinn, 2005). But much less is known about corporate elites' involvement in directly shaping the institutional design of pension funds. This gap in knowledge will have to be filled. Last but not least, while this paper has concentrated on the activities of socio-economic actors, the fiscal centred perspective on welfarestate development suggests that state actors such as civil servants and politicians may also promote their own views on how public and private pension funds should invest their assets rather than only pursuing social policy objectives in a strict sense (cf. Béland, 2014; Koreh, 2014; see also Béland, 2006; Patashnik, 2000). An emerging research agenda on the welfare-finance nexus should investigate these actors’ role. 


\section{REFERENCES}

Albert, M. (1993) Capitalism against Capitalism. London: Whurr Publishers (first published in French by Editions du Seuil, Paris, 1991).

Barre, R. (1984) Réflexions pour demain. Paris: Hachette, coll. Pluriel.

Beffa, J.-L., Boyer, R., and Touffut, J.-P. (1999) 'Les relations salariales en France : État, enterprises, marchés financiers’, Notes de la Fondation Saint-Simon, nr 107.

Beffa, J.-L., Briet, R., and Le Duigou, J.-C. (2005) 'Pour un fonds de réserve des retraites ambitieux', Les Echos, 6 December.

Béland, D. (2006) 'The Politics of Social Learning: Finance, Institutions, and Pension Reform in the United States and Canada', Governance, 19(4): 559-583.

Béland, D. (2014) 'The Fiscal Side of Social Policy: Pension Reform and the Payroll Tax in the United States and Canada', mimeo.

Bollon, P. and Cossic, G. (1997) 'La «Loi Thomas» : un dispositif permettant d'assurer l'avenir des retraites des salariés du secteur privé', Revue d'Economie Financière, nr 40(2-1997): 263-272.

Burtless, G. (2003) 'What Do We Know about the Risk of Individual Account Pensions? Evidence from Industrial Countries', American Economic Review 93(2): 354-359.

Charpentier, F. (1997) Retraites et fonds de pension : L'état de la question en France et à l'étranger. Paris: Economica ( $2^{\text {nd }}$ edition).

Chaves Jardim (2013) Syndicats et fonds de pension durant le gouvernement Lula. Paris: L'Harmattan.

Clark, G. L. (2000) Pension Fund Capitalism. Oxford: Oxford University Press.

Clark, G. L. (2003) European Pensions and Global Finance. Oxford: Oxford University Press.

Conceição-Heldt, E. (2006) 'France: The Importance of the Electoral Cycle’ In E.M. Immergut, K.M. Anderson and I. Schulze (Eds.), The Handbook of West European Pension Politics. Oxford: Oxford University Press.

Culpepper, P. (2011) Quiet Politics and Business Power: Corporate Control in Europe and Japan. New York, NY: Cambridge University Press.

Davis, E. P. (1995) Pension Funds: Retirement-Income Security and Capital Markets. An International Perspective. Oxford: Clarendon Press. 
Dixon, A. (2008) 'The Rise of Pension Fund Capitalism in Europe: An Unseen Revolution?', New Political Economy 13(3): 249-270.

Dixon, A. (2014) New Geography of Capitalism: Firms, Finance and Society. Oxford: Oxford University Press.

Dixon, A. and Sorsa, V.-P. (2009) 'Institutional Change and the Financialisation of Pensions in Europe', Competition and Change, 13(4): 347-367.

Ebbinghaus, B. (ed.) (2011) Varieties of Pension Governance: The Privatization of Pensions in Europe. Oxford: Oxford University Press.

Engelen, E. (2003) 'The Logic of Funding: European Pension Restructuring and the Dangers of Financialisation’ Environment and Planning A 35(8): 1357-1372.

Estévez-Abe, M. (2001) 'The Forgotten Link: The Financial Regulation of Japanese Pension Funds in Comparative Perspective', In B. Ebbinghaus and P. Manow (eds) Comparing Welfare Capitalism: Social Policy and Political Economy in Europe, Japan and the USA. London: Routledge.

FFSA (1991) Assurer l'avenir des retraites. Paris: SCEPRA Risques / Fédération française des sociétés d'assurance.

Fung, A., Hebb, T. and Rogers, J. (2001) Working Capital: The Power of Labor's Pensions. Ithaca, NY: Cornell University Press.

Ghilarducci, T. (1992) Labor's Capital: The Economics and Politics of Private Pensions. Cambridge, MA: MIT Press.

Ghilarducci, T., Hawley, J. and Williams, A. (1997) 'Labour's Paradoxical Interests and the Evolution of Corporate Finance', Journal of Law and Society 24 (1): 2643.

Gourevitch, P. A. and Shinn, J. (2005) Political Power and Corporate Control: The New Global Politics of Corporate Governance. Princeton, NJ: Princeton University Press.

Habbard, P. (2011) 'The Stewardship of European Workers' Capital in Times of Crisis', Transfer, 17(1): 59-73.

Hacker, J. S. (2002) The Divided Welfare State: The Battle over Public and Private Social Benefits in the United States. New York: Cambridge University Press.

Hacker, J. S. (2004) 'Privatizing Risk without Privatizing the Welfare State: The Hidden Politics of Social Policy Retrenchment in the United States', American Political Science Review 98(2): 243-260.

Hacker, J. S. (2006) The Great Risk Shift: The New Economic Insecurity and the Decline of the American Dream. New York, NY: Oxford University Press. 
Häusermann, S. (2006) 'Changing Coalitions in Social Policy Reforms: The Politics of New Social Needs and Demands', Journal of European Social Policy 16(1): 521.

Häusermann, S. (2010) The Politics of Welfare State Reform in Continental Europe: Modernization in Hard Times. New York, NY: Oxford University Press.

Immergut, E. M., Anderson, K. M. and Schulze, I. (eds) (2006) The Handbook of West European Pension Politics. Oxford: Oxford University Press.

Institut de l'Entreprise (1991) Stratégie du capital et de l'actionnariat. Rapport du groupe de travail de l’Institut de l'entreprise co-présidé par Michel Pébereau, PDG du CCF, et Arnaud Leenhardt, PDG de Vallourec. 1 July. Paris: Institut de l'Entreprise.

Jacoby, S. (2008) 'Finance and Labor: Perspectives on Risk, Inequality, and Democracy', In C. Brown, B.J. Eichengreen and M. Reich (eds) Labor in the Era of Globalization. New York: Cambridge University Press.

Jackson, G. and Vitols, S. (2001) 'Between Financial Commitment, Market Liquidity and Corporate Governance: Occupational Pensions in Britain, Germany, Japan and the USA', In B. Ebbinghaus and P. Manow (eds) Comparing Welfare Capitalism: Social Policy and Political Economy in Europe, Japan and the USA. London: Routledge.

Kessler, D. and Strauss-Kahn, D. (1982) L'épargne et la retraite : l'avenir des retraites préfinancées. Paris: Economica.

Koreh, M. (2014) 'Political Economy of Social Insurance: Toward a Fiscal-Centered Framework of Analysis', mimeo.

La Croix (1998) 'Présentation des orientations des futurs fonds de pension', 12 February.

Langley, P. (2008) The Everyday Life of Global Finance: Saving and Borrowing in Anglo-America. Oxford: Oxford University Press.

La Tribune (1997) 'Strauss-Kahn veut rouvrir le chantier des fonds de pension’, 9 July.

La Tribune (1998) 'La CGT est d'accord pour une "refondation" des retraites', 22 December.

Lazonick, W. and O’Sullivan, M. (2000) 'Maximizing Shareholder Value: A New Ideology for Corporate Governance’ Economy and Society 29(1): 13-35.

Le Duigou, J.-C. and Toulisse, J.-M. (1999) L'avenir des retraites. Paris: Les Editions de l'Atelier. 
Leimgruber, M. (2008) Solidarity without the State? Business and the Shaping of the Swiss Welfare State, 1890-2000. Cambridge: Cambridge University Press.

Leimgruber, M. (2012) 'The Historical Roots of a Diffusion Process: The Three-Pillar Doctrine and European Pension Debates, 1972-1994', Global Social Policy 12(1): 24-44.

Le Monde (1992) 'La retraite par capitalisation M. Bérégovoy sur la piste des fonds de pension', 11 March.

Le Monde (1997a) 'L'Elysée et le gouvernement rivalisent auprès des marchés', 11 December.

Le Monde (1997b) 'Le gouvernement veut relancer les fonds de pension pour dynamiser la Bourse', 11 December.

Le Monde (1998a) 'Concilier l'éthique et la finance’, 5 September.

Le Monde (1998b) 'Nicole Notat prête à "causer" des fonds de pension', 21 December.

Les Echos (1996a) 'Interview: Jean-Louis Beffa juge dix ans de privatisations à la française’, 25 November.

Les Echos (1996b) 'Epargne-retraite : Les députés ont adopté par dix voix contre quatre la réforme instituant un nouvel étage de retraite’, 25 November.

L'Express (1978) 'Vie des cadres - La retraite de plus en plus chère', 25 November.

Libération (1999) 'Retraites - le grand débat. Eviter les clivages entre jeunes et vieux, public et privé', 10 March.

Manow, P. (2001) Globalization, Corporate Finance, and Coordinated Capitalism: Pension Finance in Germany and Japan, MPIfG Working Paper, 01/5. Cologne: Max Planck Institute for the Study of Societies.

Mares, I. (2003) The Politics of Social Risk: Business and Welfare State Development. Cambridge: Cambridge University Press.

Martin, I. W., Mehrotra, A. K., and Prasad, M. (2009) 'The Thunder of History: The Origins and Development of the New Fiscal Sociology', In I. W. Martin, A. K. Mehrotra, and M. Prasad (eds) The New Fiscal Sociology: Taxation in Comparative and Historical Perspective. Cambridge: Cambridge University Press.

Meyer, T. and Bridgen, P. (2012) 'Business, Regulation and Welfare Politics in Liberal Capitalism', Policy and Politics 40(3): 387-403.

Meyer, T., Bridgen, P. and Riedmüller, B. (eds) (2007) Private Pensions versus Social Inclusion? Non-State Provision for Citizens at Risk in Europe. Cheltenham: Edward Elgar. 
Naczyk, M. (2013) 'Agents of Privatization? Business Groups and the Rise of Pension Funds in Continental Europe', Socio-Economic Review 11(3): 441-469.

Naczyk, M. and Palier, B. (2011) 'France: Promoting Funded Pensions in Bismarckian Corporatism?', In B. Ebbinghaus (ed.) Varieties of Pension Governance: The Privatization of Pensions in Europe. Oxford: Oxford University Press.

Notat, N. (2003) 'La responsabilité sociale des entreprises', Futuribles, nr 288 (JulyAugust): 11-28.

OECD (2009) Private Pensions Outlook 2008. Paris: Organisation for Economic CoOperation and Development.

Orenstein, M. A. (2013) 'Pension Privatization: Evolution of a Paradigm', Governance 26(2): 259-281.

Oude Nijhuis, D. (2013) Labor Divided in the Postwar European Welfare State: The Netherlands and the United Kingdom. Cambridge: Cambridge University Press.

Palier, B. (2007) 'Tracking the Evolution of a Single Instrument Can Reveal Profound Changes: The Case of Funded Pensions in France', Governance 20(1): 85-107.

Park, G. (2004) ‘The Political-Economic Dimension of Pensions: The Case of Japan', Governance 17(4): 549-572.

Pastré, O. and Moscovici, P. (1992) Epargne salariale et fonds propres : rapport. Paris: Ministère de l'industrie et du commerce extérieur.

Patashnik, E.M. (2000) Putting Trust in the US Budget: Federal Trust Funds and the Politics of Commitment. New York: Cambridge University Press.

Peyrelevade, J. (1993) Pour un capitalisme intelligent. Paris: Grasset.

Peyrelevade, J. (1998) 'Le "corporate governance" ou les fondements incertains d'un nouveau pouvoir’, Notes de la Fondation Saint-Simon, nr 99.

Pontusson, J. (1992) The Limits of Social Democracy: Investment Politics in Sweden. Ithaca, NY: Cornell University Press.

Renneboog, L., Ter Horst, J. and Zhang, C. (2008) 'Socially Responsible Investments: Institutional Aspects, Performance, and Investor Behavior', Journal of Banking and Finance 32(9): 1723-1742.

Roe, M. (2003) Political Determinants of Corporate Governance: Political Context, Corporate Impact. Oxford: Oxford University Press.

Seeleib-Kaiser, M., Saunders, A. M. and Naczyk, M. (2012) 'Shifting the PublicPrivate Mix: A New Dualization of Welfare?', in P. Emmenegger, S. Häusermann, B. Palier and M. Seeleib-Kaiser (eds) The Age of Dualization: The 
Changing Face of Inequality in Deindustrializing Societies. New York, NY: Oxford University Press.

Sparkes, R. (2002) Socially Responsible Investment: A Global Revolution. Chichester: John Wiley and Sons.

Swenson, P. A. (2002) Capitalists against Markets: The Making of Labor Markets and Welfare States in the United States and Sweden. New York, NY: Oxford University Press.

Théry, N. (2002) 'Le comité intersyndical de l'épargne salariale : un nouveau levier d'action syndicale', Cadres CFDT nr 400: 74-77.

Useem, M. (1996) Investor Capitalism: How Money Managers are Changing the Face of Corporate America. New York, NY: Basic Books.

van der Zwan, N. (2014) 'Making Sense of Financialization', Socio-Economic Review 12(1): 99-129. 